\title{
DID A PALESTINE SPRING TAKE PLACE? THE LOST DECADE IN PALESTINE
}

\author{
Philipp O. AMOUR \\ Assistant Professor, Department of International Relations \& Middle East Institute, Sakarya University
}

\begin{abstract}
The Palestinian political system has been struck since 2007 by political and ideological feuding between Fatah and Hamas. The occupied Palestinian territories (OPT) have been politically divided between the PNA-governed West Bank and Hamas-controlled Gaza Strip. This strategic framework has destructive implications for Palestinian politics and civil space given the hegemonic positions of both rival factions. Inter-movement enmity and the lack of willingness to reach national reconciliation have stalled presidential and legislative elections since 2010 and debilitated the Palestinian cause in the international arena. The Arab Spring movement, in its initial state, delivered to Palestinians a revolutionary stimulus and a strategic window to challenge domestic politics. In retrospect, however, the Palestine Spring proved to be short-lived and ineffective in achieving the demanded politico-economic reforms and national unification of Fatah and Hamas. The article suggests two main factors, among others: (1) the fiasco of the national movement / project and as a result the lack of a hierarchical and organizational role model for the social movement to emulate and (2) the occupational context of the Palestinian case that absorbs public discomfort and decreases the possibility of a mass social movement (a far-reaching Palestine Spring) against historical leadership.
\end{abstract}

Keywords: Palestine Spring, Third Intifada, Fatah, Hamas, Reconciliation, Division.

\section{$\ddot{O} z$}

\section{Filistin Baharı Gerçekleşti mi? Filistin'deki Kayıp On Yıl}

Filistin'in siyasi sistemi, Fetih ve Hamas arasında devam eden politik ve ideolojik kavga nedeniyle 2007 yılından bu yana sıkışmış vaziyettedir. Filistin'in işgal edilmiş toprakları, Batı Şeria'yı yöneten Filistin Ulusal Otoritesi (PNA) ile Gazze Şeridi'ni kontrol eden Hamas arasında siyasi olarak ikiye bölünmüştür. Sözkonusu stratejik çerçeve rakip iki grubun hegemonik pozisyonları dikkate alındığında hem Filistin siyasetinde hem de sivil alanda yıkıcı etkilere sebep olmuştur. Karşılıklı düşmanlık ve ulusal uzlaşmaya varma konusundaki isteksizlik, 2010 yılından bu yana başkanlık ve yasama seçimlerini kesintiye uğratarak Filistin davasını uluslararası alanda zayıflattı. Arap Baharı hareketi başlangıçta Filistinlilere devrimsel bir uyarıcı ve iç siyasette mücadele etmek için stratejik bir pencere sundu. Ancak geçmişe bakıldığında, Filistin Baharı, talep edilen politik-ekonomik reformlara ulaşmada ve Fetih ile Hamas'ın ulusal birliğini gerçekleştirmede kısa süreli ve etkisiz kaldığını kanıtladı. Makale diğer faktörlerin yanında iki ana faktör önermektedir: (1) ulusal projenin fiyaskosu ve bunun sonucu olarak toplumsal hareket tarafindan öykünülecek hiyerarşik ve örgütsel bir rol modelinin eksikliği; (2) ve Filistin davasının, halkın sıkıntısını absorbe eden ve devrimci liderliklere karşı radikal bir devrimci değişim (kitlesel Filistin toplumsal hareketi) olasılı̆̆ını azaltan işgalci bağlamı.

Anahtar Kelimeler: Arap Baharı, Filistin Baharı, Üçüncü İntifada, İsrail, PLO, PNA, Fetih, Hamas, Ortadoğu, Kayıp on yıl, Fetih-Hamas ayrılığ 1

Corresponding author/Sorumlu yazar: Philipp O. AMOUR, dr@philipp-amour.ch Submitted/Geliş Tarihi: 28.01.2018 Accepted/Kabul Tarihi: 23.05 .2018

DOI: 10.26650 /TurkJHist.2018.384983

Cite this article as: Philipp O. Amour, "Did a Palestine spring take place? The lost Decade in palestine", Turkish J Hist (2018), 151-176. 


\section{Introduction}

From the perspective of the Palestinians, the onset of the so-called Arab Spring movement in the Middle East represented a simple morality tale about regional politics because Arabs were and are not alone in their aspirations to overturn the status quo that is perceived to be unjust ${ }^{1}$. For Palestinians and other Arabs, the struggle for self-determination draws upon aspirations for a better future and is driven by similar political and economic grievances. The question of Palestine is generally understood as a legacy of colonialism by both local and international observers, having sprung from the same post-World War II ethos as many of the Arab regimes that were the target of the so-called Arab Spring uprisings ${ }^{2}$. The underlying political context is quite similar, reflecting the desire for justice and emancipation after decades of suppression ${ }^{3}$. However, whereas the rebellions and grievances of other Arab populaces were primarily directed at their own repressive regimes, the Palestinians directed their grievances against the Palestinian National Authority (hereafter PNA) and its major political arm Fatah against the Islamic Resistance Movement (hereafter Hamas), in addition to the Israeli occupation.

Contemporary Arab uprisings generated an authentic and undeniable zeitgeist of change and anticipation in the Middle East. However, as later dynamics have exposed, the outcomes of these uprisings varied around dysfunctional/failed transition (e.g., Libya and Egypt) and civil war (e.g., Yemen and Syria). Such outcomes do not match the major shift that was anticipated across the Middle East. The Arab Spring movement has proven disruptive to the long-seated regional system in the Middle East. It has intensified power competition and regional rivalry throughout the region between two rival blocs: the (Saudi-led) neoconservative-moderate bloc and the (Iran-led) neoconservative-resistance bloc ${ }^{4}$. Regional great powers used means

1 The 'Arab Spring' is the most frequently used term - among other terms such as Arab uprisings, Arab Awakening, Arab revolutions - describing the wave of rebellions and related events, with a variety of implications, which have occurred since December 2012. Michelle Pace and Francesco Cavatorta, "The Arab Uprisings in Theoretical Perspective - An Introduction," Mediterranean Politics 17, no. 2 (July 2012): 125-138.

2 Nicola Pratt, "The 'Arab Spring' and the Israel-Palestine Conflict: Settler Colonialism and Resistance in the Midst of Geopolitical Upheavals," Ortadoğu Etütleri (Journal of Politics and International Relations) 5, no. 1 (July 2013): 17-23; see also Hamid Dabashi, The Arab Spring: The End of Postcolonialism (London; New York : New York: Zed Books ; Distributed in the USA exclusively by Palgrave Macmillan, 2012).

3 See, e.g., Hannan Ashrawi, "Palestine and the Arab Spring", Summary of Discussion Hosted by Carnegie Endowment for International Peace" (Washington DC, 2011), http://carnegieendowment. org/2011/05/27/palestine-and-arab-spring/1qb (accessed 09 Mai 2013).

$4 \quad$ Philipp O. Amour, ed., The Middle East Reloaded: Revolutionary Changes, Power Dynamics, and Regional Rivalries since the Arab Spring, St. James's Studies in World Affairs (Washington, DC: Academica Press, 2018). 
of soft and hard power to shape the outcomes of the Arab Spring movement or to reverse such revolutionary outcomes in agreement with their strategic advantage. They supported their historical allies diplomatically, financially and militarily to avoid a domino effect of the Arab Spring movement or to withstand unfolding revolutionary transactions.

Islamic-based insurgencies in specific countries (e.g., Tunisia, Egypt, and Morocco) have heightened regional uncertainty and insecurity of established regional blocs. Had they prospered beyond 2013, the new political leaderships would likely have attempted changes in their alliance patterns both inward and outward. These novel leaderships became allied in what could be termed elected-'reformist' blocs that attempted to represent transnational principles, consolidate revolutionary outcomes, and withstand the authoritarian gravity of the other mentioned blocs. This multipolarity saw the different blocs in unrelenting competition in diplomatic battles, media wars and proxy wars 5 . External actors have thus contributed to the outcome of regional dynamics and transition period as is evident in Bahrain, Syria, Yemen, and Libya ${ }^{6}$.

Palestine was in some respects no exception. The regional drive after 2011 produced high spirits and high hopes for a better future. With this authentic drive, the Palestinians felt that they had substantial momentum to fulfil their national aspirations, which appeared to be realistic ${ }^{7}$. For the Palestinians, regional dynamics after 2011 seemed to spawn a strategic context for radical change, including the possibility of reconciliation and rapprochement between (in alphabetical order) the Palestine National Liberation Movement (hereafter Fatah) and Hamas and full statehood recognition by the United Nations Security Council (UNSC), in addition to the end of the Israeli occupation ${ }^{8}$.

$5 \quad$ Philipp O. Amour, "Revolutionary Changes, Power Dynamics, and Regional Rivalries since the Arab Spring: An Introduction," in The Middle East Reloaded: Revolutionary Changes, Power Dynamics, and Regional Rivalries since the Arab Spring, ed. Philipp O. Amour, St. James's Studies in World Affairs (Washington: Academica Press, 2018), 1-21.

6 Philipp O. Amour, "The Arab Spring Movement: The Failed Revolution. Preliminary Theoretical and Empirical Deliberation," in The Middle East Reloaded: Revolutionary Changes, Power Dynamics, and Regional Rivalries since the Arab Spring, ed. Philipp O. Amour, St. James's Studies in World Affairs (Washington: Academica Press, 2018), 199-224.

7 For the aspect of hope see Avi Shlaim, "Israel, Palestine, and the Arab Uprisings," in The New Middle East: Protest and Revolution in the Arab World, ed. Fawaz A. Gerges (New York: Cambridge University Press, 2014), 381, 388.

8 The Palestinian youth recognized the Arab Spring movement as a model and stimulus for their social movement. See Noura Erakat, "Palestinian Youth: New Movement, New Borders," Aljazeera, last modified May 4, 2011, accessed April 3, 2016, http:/www.aljazeera.com/indepth/featu res/2011/05/201153101231834961.html. 
However, the Palestinian cause is not merely moral in nature; in fact, it is far more challenging. It is a prime example of realist politics (IR), in which international constellations and geostrategic regional objectives play a lead role in local particularity. Despite its centrality in regional affairs ${ }^{9}$, the Palestinian cause was not a core issue of the Arab Spring uprisings per $\mathrm{se}^{10}$; with few exceptions, the Palestine issue was missing from these revolutionary movements ${ }^{11}$.

To a certain level, the inter-party split between Fatah and Hamas has proven to be a side effect of regional interactions. The reaction of external power to the Arab Spring movement is important to correctly explain the course of events in potential Arab Spring cases as in Palestine ${ }^{12}$. A Palestine Spring would have an impact on the Palestinian leadership and on the relations they obtain with external state and non-state actors. It may bring to power a novel elite that would switch commitment from long established alliances to a novel one and would support a shift in the balance of power in the Middle East to the advantage of one alliance against other. Such a scenario would inspire like-minded resistance movements in other countries in the Middle East. Due to its centrality in transnational affairs, higher states in the Middle East intervened in the Palestinian case and attempted to shape the outcome of a national reconciliation to see a rise in their influence ${ }^{13}$.

The failure of the reconciliation agreements between Fatah and Hamas to materialize and the debacle regarding the full acknowledgment of a sovereign Palestinian state in the United National Security Council (UNSC) were pivotal setbacks for Palestinians seeking to exploit the regional dynamics. Against this background, the regional dynamics since 2010 have not materialized as a constructive strategic context for Palestinians; Palestine is neither unified nor fully recognized.

$9 \quad$ Morten ValbjøRn and André Bank, "The New Arab Cold War: Rediscovering the Arab Dimension of Middle East Regional Politics," Review of International Studies 38, no. 01 (January 2012): 5, 9-12.

10 Roberto Aliboni, "The International Dimension of the Arab Spring," The International Spectator 46, no. 4 (December 2011): 7; Haim Bresheeth, "The Arab Spring: A View from Israel," Middle East Journal of Culture and Communication 5, no. 1 (January 1, 2012): 47.

11 Reem Abou-El-Fadl, "The Road to Jerusalem through Tahrir Square: Anti-Zionism and Palestine in the 2011 Egyptian Revolution," Journal of Palestine Studies 41, no. 2 (January 2012): 6-26.

12 See: Sverre Lodgaard, External Powers and the Arab Spring (Oslo: Scandinavian Academic Press, 2016); Marc Lynch, The New Arab Wars: Uprisings and Anarchy in the Middle East (United States of America: Public Affairs, 2017).

13 Philipp O. Amour, "Hamas-PLO/Fatah Reconciliation and Rapprochement within the Unfolding Regional Order in the Middle East since 2010: Neorealist and Neoclassical Realist Perspectives," Journal of Social Sciences of Mus Alparslan University 6, no. 5 (April 13, 2018): 621-31, https:// doi.org/10.18506/anemon.384773. 
The Arab Spring movement took place in different ways. In states such as Tunisia, Egypt, Libya and Yemen, protestors demanded the collapse of the regime. In other states, such as Jordan and Morocco, they demanded political and economic reforms. The current academic article suggests that the Arab Spring movement did not sidestep Palestine. Rather, the Arab Spring movement reached the occupied Palestinian territories in major waves, as Palestinians have grounds to join the Arab Spring movement and rise up against their leadership. However, the article concludes that the Palestine Spring is a corresponding manifestation of the second category mentioned above, in the sense that the social movement did not demand a radical shift in the governmental institutions or leadership elite. Instead, protestors gained political compromises from the ruling parties, Fatah and Hamas. Two major factors may explain such an orientation of the social movement.

First, the occupational framework of the Palestinian case. The discontent against Fatah and Hamas interacted in opposition with external affairs such as wars against the Gaza Strip or diplomatic struggles against the Palestine Liberation Movement (hereafter PLO) in the wake of the application for recognition by the $\mathrm{UN}$. The magnitude of such external factors impacted public attitudes and discontent towards the ruling parties, Fatah and Hamas. The conclusion of this article is that a higher magnitude of such factors led to a decrease in public discontent against Fatah and Hamas.

Secondly, the article concludes that the social movement was fragmented and lacked the organizational and hierarchical capabilities required for a promising revolution. At first glance, the Palestinian case demonstrates a context ripe for revolutionary uprising against the leadership. Yet, there appears to be an interaction between, on the one hand, the failure of the Palestinian revolution (in particular Fatah and Hamas) and the perceived lack of a role model for political mobilization and activism and, on the other hand, the lack of willingness among young Palestinians for organizationally and hierarchically organized social movements capable of organizing long-lasting and self-generating actions in the social space.

The following sections attempt to answer the following questions: What were the objectives of the Palestine Spring? Who were the protagonists of the waves of protests? Why did the social movement fail to achieve its objectives, and what implications did it have for the rival parties, Fatah and Hamas? The article is structured in specific sections to answer these questions.

\section{The Arab Spring in Palestine: Did a Palestine Spring take place?}

The contemporary Arab Awakening was long awaited and much celebrated, and it seemed to evince an acute and persistent shift in the Middle East. Political interactions from Tunisia in 2010 to Syria/Yemen/Libya in 2018 left their marks on 
society and the political elite across the Middle East. Palestine was no exception. Shortly after the collapse of the Mubarak administration in Egypt, the Arab Spring movement reached the occupied Palestinian territories (OPT) in two main waves.

The first wave that began in early 2011 strove to promote political reforms and national reconciliation between Fatah and Hamas ${ }^{14}$. The unifying mantra of the social movement was "The people want to end the division" ${ }^{15}$ !" Since 2007, after a successful takeover of power by Hamas in the Gaza Strip, the PNA had been divided into two entities: the Hamas-dominated government in the Gaza Strip and a second Fatah-controlled government in the West Bank. A novel social movement spurred peaceful protests that challenged the political hegemony of the PNA/Fatah in the West Bank and Hamas in the Gaza Strip ${ }^{16}$. The discontent and protests that swept over the OPT against Fatah and Hamas marked historically unprecedented trends. Palestinian protests had usually been directed against the Israeli occupation and Israeli soldiers. The Israeli occupation had so far protected the Palestinian leadership from ground-breaking discourse challenging their political legitimacy and questioning their historical revolutionary credibility and institutional establishment. Remarkably, the novel social movement embodied unpredictable and contentious protagonists of political and civil shift. As a later section will demonstrate, several groups took part in these demonstrations, with no central hierarchy managing or coordinating them ${ }^{17}$.

Initially, both Fatah and Hamas turned a deaf ear to the demands of the people in the streets regarding political reforms and national unification. Moreover, both Fatah and Hamas deployed tactics to prevent the escalation of the protests and to contain the burgeoning social movement ${ }^{18}$. However, the intensity of the demonstrations forced both ruling parties to reconsider their attitude towards protestors and domestic affairs. The regional context and the nature of the public demonstrations provided support for this reconsideration. As the uprisings in Tunisia and Egypt have demonstrated, such public movements are fluid and unpredictable and may set in motion the collapse of the political leadership as part of the formula

14 Rawan Abu-Shahla, "Why Palestinians Will Protest on 15 March," The Electronic Intifada, last modified March 14, 2011, accessed December 16, 2017, https://electronicintifada.net/content/ why-palestinians-will-protest-15-march/9823.

15 Asmaa Al-Ghoul, "Palestinian Activists Bemoan Their Lost Arab Spring," Al-Monitor, last modified January 18, 2013, accessed January 4, 2018, https://www.al-monitor.com/pulse/originals/2013/01/palestine-failed-arab-spring.html.

16 Erakat, "Palestinian Youth."

17 See Guy Burton, "Building Ties across the Green Line: The Palestinian 15 March Youth Movement in Israel and Occupied Palestinian Territory in 2011," Third World Quarterly 38, no. 1 (January 2, 2017): 169, 175.

18 Abu Toameh, "Palestinian Affairs: Will the Palestinians Rise up Too?," The Jerusalem Post, last modified March 11, 2011, accessed August 8, 2014, http://www.jpost.com/LandedPages/PrintArticle.aspx?id=211680. 
for social change ${ }^{19}$. Moreover, the social movement gave strong expression to a growing discontent throughout the occupied Palestinian territories ${ }^{20}$. These dynamics gave the executive leadership a reason for concern, particularly given that the social movements in Tunisia and Egypt demonstrated their capabilities in effecting political change. As a result, both Fatah and Hamas emphasized their (half-hearted) desire for unification ${ }^{21}$. The loss of regional allies, Egypt (Fatah) and Syria (Hamas), provided yet another reason for this reorientation ${ }^{22}$.

Against this background, the representatives of Fatah and Hamas held a series of meetings in Egypt and Qatar to reach a unity accord. In May 2011, the Cairo reconciliation agreement was signed between Fatah and Hamas under the auspice of the newly formed Egyptian leadership (the Supreme Council of the Armed Forces). The two rival movements agreed to form a national unity government and to organize parliamentary and presidential elections ${ }^{23}$. Another reconciliation deal was brokered in Qatar in January $2012^{24}$. These reconciliation deals likely absorbed public contention directed at Fatah and Hamas while anticipating national unity. However, implementing the terms of these reconciliation agreements has proven difficult, and their failure gradually occurred due to internal and external factors ${ }^{25}$.

19 Dag Tuastad, "Hamas-PLO Relations Before and After the Arab Spring," Middle East Policy 20, no. 3 (September 2013): 86.

20 Mona Christophersen, Jacob Høigilt, and Åge A. Tiltnes, Palestinian Youth and the Arab Spring (Norway: Norwegian peacebuilding resource centre (NOREF), February 2012), http://www. peacebuilding.no/var/ezflow_site/storage/original/application/562d62ccb49d92227b6865a8b2d11e1a.pdf.

21 Erakat, "Palestinian Youth."

22 Khaled Elgindy, "The Palestinians: Between National Liberation and Political Legitimacy," in The Arab Awakening: America and the Transformation of the Middle East, Saban Center at the Brookings Institution book (Washington, DC: Brookings Institution Press, 2011), 134.

23 Jason Brownlee, Democracy Prevention: The Politics of the U.S.-Egyptian Alliance (Cambridge [England] New York: Cambridge University Press, 2012), 163; “Agreement between Fatah and Hamas,” May 3, 2011, accessed May 20, 2015, http://peacemaker.un.org/sites/peacemaker.un.org/ files/OPt_AgreementFatahHamas2011.pdf; Ashraf Ezzat, “"Third Intifada Underway', Dissident Voice, 9 May 2011," Third Intifada Underway, last modified May 9, 2011, accessed March 3, 2012, http://dissidentvoice. org/2011/05/third-intifada-underway; Pratt, "The 'Arab Spring' and the Israel-Palestine Conflict," 13.

24 “Abbas to Head Palestinian Unity Government," Al Jazeera English, last modified February 7, 2012, accessed May 20, 2015, http://www.aljazeera.com/news/middleeast/2012/02/20122610416298264.html; see also Jodi Rudoren and Akram Fares, "Palestinians Sign Deal to Set Up Elections," NYTimes.Com, last modified May 20, 2012, accessed May 20, 2015, http://www.nytimes.com/2012/05/21/world/middleeast/hamas-and-fatah-agree-in-cairo-tobegin-work-on-elections.html?_r=0.

25 Nadia Naser-Najjab, "Palestinian Youth and the Arab Spring. Learning to Think Critically: A Case Study," Contemporary Arab Affairs 5, no. 2 (April 2012): 281, https://doi.org/10.1080/175 50912.2012.672000; Amour, "Hamas-PLO/Fatah Reconciliation and Rapprochement within the 
The second main wave of demonstrations (September 2012) focused on economic grievances. It touched upon high prices and unemployment in the occupied Palestinian territories and called for the removal of economic restrictions under the Paris Protocol. Although the demonstrations did not lead to the amendment of the Paris Protocol ${ }^{26}$, they caused public outrage against the PNA. The President of the PNA, Mahmoud Abbas, used the Palestinian Prime Minister Salam Fayyad as a scapegoat to bring the crisis facing him under control, thus appeasing the anger of protestors during this wave. Prime Minister Fayyad's government resigned the following year ${ }^{27}$.

Since the end of the Arab Spring ${ }^{28}$, popular demonstrations have been taking place calling for unity between Fatah and Hamas $^{29}$. However, whereas protests against the Israeli occupation are frequent, social movement mobilization against the ruling parties, Fatah and Hamas, have faded since 2013 due to a combination of factors concerning infiltration by Fatah and Hamas, targeted detentions by Palestinian and Israeli security forces, challenged mobility due to security posts, and a fragmented social movement ${ }^{30}$. Such factors will be explained below in the related section. While social movement mobilization calling for political reforms in Palestine has thawed since 2013, grassroots and social movement mobilization against the Israeli occupation and sanctions against the OPT remained frequent and constant ${ }^{31}$.

Unfolding Regional Order in the Middle East since 2010:"

26 Lena Odgaard, "Protesters Signal Political Crisis For the Palestinian Authority," Al-Monitor: The Pulse of the Middle East, last modified September 10, 2012, accessed May 10, 2015, http:// www.al-monitor.com/pulse/originals/2012/al-monitor/do-not-publish--west-bank-protes.html\#; "Will We Always Have Paris?," Gaza Gateway | Facts and Analysis about the Crossings, last modified September 13, 2012, accessed May 10, 2015, http://gisha.org/en-blog/2012/09/13/willwe-always-have-paris/; Barak Ravid, "Fayyad's Resignation: The Beginning of the End of the PA?," Haaretz Online, April 14, 2013, accessed May 2, 2013, http://www.haaretz.com/news/middle-east/fayyad-s-resignation-the-beginning-of-the-end-of-the-pa-1.515292.

27 "Salam Fayyad," The New York Times, accessed May 15, 2014, http://topics.nytimes.com/top/ reference/timestopics/people/f/salam_fayyad/index.html.

28 Philipp O. Amour, "Editor's Note: The End of the Arab Spring?," ed. Philipp O. Amour, The Arab Spring: Comparative Perspectives and Regional Implications 12, no. 3, Special issue, Alternatives: Turkish Journal of International Relations (Fall 2013): I-IV; Philipp O. Amour, "Israel, the Arab Spring, and the Unfolding Regional Order in the Middle East: A Strategic Assessment," British Journal of Middle Eastern Studies 44, no. 3 (July 3, 2017): 293-309.

29 "Palestine: Palestinian Authority Police Beat Protesters," HRW, last modified July 30, 2013, accessed January 10, 2018, https://www.hrw.org/news/2013/07/30/palestine-palestinian-authority-police-beat-protesters.

30 For these factors see e.g., Burton, "Building Ties across the Green Line," 170.

31 See e.g., Ghada Ageel, "A Palestinian Uprising: Is It Possible or Is It Too Late?," Sociology of Islam 2, no. 3-4 (June 10, 2014): 283-309. 


\section{Grounds for a Palestine Spring: Do Palestinians have reasons to rise up against the PLO/Fatah/PNA?}

The Arab Spring movement nurtured the growing dissatisfaction and tensions throughout the occupied Palestinian territories and elevated political mobilization ${ }^{32}$. Indeed, Palestinians have imperative reasons for a Palestine Spring including (1) the stagnation of the national project; (2) the volatile political environment under the PNA and Hamas; (3) the dire socio-economic situation; and (4) inter-movement division between the rival movements Fatah and Hamas with foremost implications.

The PLO and its major politico-military arm Fatah have failed to establish a national independent state: a sovereign Palestine. After years of militant resistance, Fatah gave up its militant approach in favor of a moderate, peaceful grand strategy ${ }^{33}$. However, for Palestinians, the PLO's/Fatah's peace negotiation master strategy with Israel did not yield (warm) peace or the establishment of a national independent and sovereign state. Instead, the Oslo Accords established a weak PNA that governs over isolated and disconnected occupied Palestinian territories in the Gaza Strip and the West Bank. Despite its failure to create a viable independent and sovereign Palestinian state, the PLO leadership is sticking with the Oslo agreements that were supposed to establish a Palestinian state by the end of 1999. In the meantime, Israel's right-wing government building and expansion of settlements on Palestinian lands have tripled since the Oslo agreement. The same government has intensified the separation and isolation of occupied Palestinian territories and the segregation of the Palestinians.

Palestinians believe that the partially physical departure of the occupying power did not mean total independence. Bearing in mind Israel's right-wing government's expansion policy (settlements) on Palestinian land in addition to its segregation policy since the Oslo peace process, Palestinians argue that Israel's occupation over Palestinian land continues and that Israel's strategic hold persists. For moderate Palestinians, Israel did not make (its best) endeavors to facilitate the formation of a Palestinian state at the end of the Oslo Process. Instead, it used intentional sanctions and procedures to change facts on the ground and prejudice the civil and religious rights of the Palestinians. Palestinians believe that Israel did not relinquish its claims and authority over Palestine; instead, it is using the PNA to maintain its claims and authority over Palestinian lands because the economic and military costs of direct occupation far outweigh the strategic benefits. In other words, Palestinians see the PNA as a security proxy of Israel. Due to the failure in fulfilling the national

32 As'ad Ghanem, "The Palestinians - Lessons from the Arab Spring," Contemporary Arab Affairs 6, no. 3 (July 2013): 435-436.

33 See e.g., Philipp Amour, "Palestinian Politics in Transition: The Case of the October War," in The October War: Politics, Legacy, Diplomacy, ed. Asaf Siniver (London: London: Hurst C \& Co Publishers Ltd, 2013). 
project and the continuing security cooperation with Israel (despite Israel conducting demonstrations of raw power against Palestinians), Palestinians question the legacy of the PLO/Fatah/PNA. Their frustration towards the fatigue of living under occupation has directed itself against the PNA/Fatah at different times ${ }^{34}$.

Despite its failed national project, PLO/Fatah leadership refrained from attempting to follow a path towards major reforms. As if lack of reorientation were not enough, the Palestinian papers publicized in Aljazeera and the Guardian in 2011 provided an indication of the quality of Palestinian negotiators and the course of their compromises vis-à-vis Israeli negotiators. The leaked documents revealed that the Palestinian officials had made wide-ranging compromises towards Israeli officials beyond national consent on three controversial topics: Jerusalem, the fate of Palestinian refugees, and the Jewishness of the State of Israel ${ }^{35}$. Although Palestinian officials denied the authenticity of these revelations ${ }^{36}$, the PNA/Fatah had to assure Palestinians that it would not make concessions that would divide Palestinian land, thus allowing Israel to set up new physical realities on the ground. Popular support for Fatah and the PLO increasingly suffered due to the delicate information, and Palestinians demanded a reorientation of the master strategy towards Israel's rightwing government.

Interestingly, Palestinians believe that members of the old guard of the PLO have been cruelly deceived by Israel's strategic and tactical maneuvers since the Oslo process. In explaining the level and extent of the compromises, Palestinians attest that the PLO leadership adopted a Zionist agenda for Israel's domination hegemony over the historical Palestine. This has led to an increase of public discomfort and political mobilization against the old guard and the political institutions ${ }^{37}$.

This suggested poor legitimation involves members of the old guard, the socalled abus, among others, who have proven, in many aspects, to be not up to the mission of building an independent sovereign Palestinian state. While in exile, they were highly appreciated by the inland Palestinians, the political reality and their lack of competences on the ground were revealed in the post-Oslo period after their arrival in the OPT. Mythical story-telling and imaginative stories had constructed a profile

34 "Talks with Previous Gaza-based and Westbank - based Activists in Turkey," 2016, 2017 2015; Naser-Najjab, "Palestinian Youth and the Arab Spring. Learning to Think Critically," 280-281.

35 "The Palestine Papers: The Documents," The Guardian, last modified February 1, 2011, accessed May 20, 2015, http://www.theguardian.com/world/series/palestine-papers-documents; "The Palestine Papers," Al Jazeera English, last modified January 2011, accessed May 20, 2015, http:// www.aljazeera.com/palestinepapers/.

36 "Palestine Papers: Al Jazeera, Guardian Release Documents On Israeli-Palestinian Conflict," accessed May 20, 2015, http://www.huffingtonpost.com/2011/01/23/palestine-papers-israel-conflict-wikileaks-documents-released_n_812776.html\#13_harsh-words-for-all-sides.

37 "Talks with Previous Gaza-based and Westbank - based Activists in Turkey." 
of those revolutionaries, co-founders of the Palestinian national movement in exile, co-founders of the PLO, and signers of the Oslo accords. In the eyes of many Palestinians, they were seen as semi-gods. Upon their arrival in the Occupied Palestinian Territories, Palestinians had the opportunity to interact with them politically, observe the PLO elite and view and reconsider their political performance and skills. The historical credibility and legitimacy of the forefathers of the alleged revolution and leaders of the militant struggle have begun to erode. This perspective of members of the old guard as political laypersons has proven a disappointment for Palestinians.

The PNA consists of an exclusive elite group that profits economically and politically from the maintenance of the Oslo political system. Abuse of power, mismanagement and repression of human rights were and are frequent praxis. This has moved Palestinians again and again to criticize the PNA for its bad governance and dysfunctional regime ${ }^{38}$. Moreover, the exclusion of intifada generations from political opportunities minimized the rise of a younger Palestinian elite to the political hierarchy. Such practices caused a fall in the popularity of the major political factions and the old guard in particular. In addition, it has increased the 'insider'-'outsider' cleavages among Palestinians.

The executive (president) and legislative (the Palestinian Legislative Council) bodies do not have legal status according to democratic standard due to the conclusion of their mandate in 2010. The Palestinian President, Mahmoud Abbas, was elected in 2005. His administration expired in 2009. This proscribed status has since delegitimized the unification governments ${ }^{39}$. One reason for the delay of parliamentary and presidential elections is the national rift between Fatah and Hamas. The demand for national rapprochement thus underlies the expectation of a regeneration of the Palestinian political systems and progress in socio-economic affairs.

The abovementioned strategic framework is not without costs and limitations for Palestinian politics and civil space given the hegemonic positions of both rival factions in the political establishments. Thus, demonstrations in the OPT addressed the stalemate of politics in and on Palestine and as such reflect a deep frustration towards the policy-makers. It thus reminded the political elite of their failure to put an end to national divisions and disagreements and to build a viable, independent and sovereign Palestinian state. While these factors may demonstrate that the Palestine case is ripe for a Palestine Spring, the following sections will show that no

38 Derek Stoffel, "Palestinian Youth Uprising Faces Uncertainty as Clashes with Israel Increase," CBC News, last modified November 17, 2014, accessed January 9, 2018, http://www.cbc.ca/news/ world/palestinian-youth-uprising-faces-uncertainty-as-clashes-with-israel-increase-1.2837116.

39 "How Did the Palestinian National Unity Government Perform during Its First Year [in Arabic]?," Arab Reality (Aljazeera Net, June 2, 2015), http://www.aljazeera.net/programs/arab-present-situation/2015/6/2. 
social disobedience against the political elite took place due to the lack of a social dynamic, revolutionary narrative, and organizational structure.

\section{Who were the protagonists of the Palestine Spring?}

Who were the protagonists of the uprising? My analysis demonstrates three trends. The first group includes protesters of previous affiliation to a classical resistance movement such as Fatah or Hamas. Exclusion from state sector employment or dissatisfaction with the political engagement of the political leadership mentioned above distanced many followers of the first Intifada and second Intifada generations from their initial political movements. Contrary to other Arab contexts, these generations broke the barrier of fear with regard to demonstrations earlier in two major Intifadas. In the light of the revolutionary stimuli in the Middle East, they gathered momentum to express their contention.

The second group involved a social movement with reformist tendencies and an independent political affiliation ${ }^{40}$. This group represents a reformist politicking ensuing from generational change, the youthful segment. This included, above all, protesters between 18 and 35 years of age including students, university graduates and unemployed Palestinians ${ }^{41}$. After the Al-Aqsa-intifada, a younger generation arose with increasing access to global governance and the liberal spectrum of ideas and ideals, thus widening their worldviews and perspectives of contemporary politics. Furthermore, their prior political disengagement made them quite independent from the classical movements, thus empowering them as a potential driver for radical change in Palestine. However, their apathy toward traditional political parties in Palestine most likely made them inclined to hierarchical and organizational mobilization ${ }^{42}$. A third group included organizations such as women's and students' organizations ${ }^{43}$.

The abovementioned groups built opposition against the status quo of Palestinian politics. Like their counterparts in Tunisia, Egypt, and elsewhere, they were spontaneous at the beginning. Their activities varied, including non-violent marches, protests, hunger strikes and cultural events ${ }^{44}$, as well as the use of social media ${ }^{45}$.

40 Elgindy, "The Palestinians," 128-136.

41 Burton, "Building Ties across the Green Line," 6.

42 Youth Poll on Politics, Social Media and Conservatism, Poll (Jerusalem: The Jerusalem media and communication centre (JMCC), April 2016), accessed January 6, 2018, http://www.jmcc. org/documentsandmaps.aspx?id=871; Youth Poll on Politics, Education \& The Future, Poll (Jerusalem: The Jerusalem media and communication centre (JMCC), October 9, 2016), accessed December 6, 2018, http://www.jmcc.org/documentsandmaps.aspx?id=873.

43 See Ageel, "A Palestinian Uprising."

44 See e.g., Richard Carlton Snyder et al., eds., Foreign Policy Decision-Making Revisited (New York: Palgrave Macmillan, 2002), 173.

45 See Natasha Mozgovaya, "Gaza, the Most Facebook Friendly Place on Earth," Haaretz Online, 
Notably, the protagonists of these activities delivered alternative forms of non-violent and peaceful resistance in comparison to the social movements that dominated the first and second Intifadas ${ }^{46}$.

\section{Why did the social movement fail to achieve Palestine Spring demands?}

In retrospect, the social movement in the OPT did not generate radical changes in domestic political or economic affairs due to a number of interrelated factors. First, external behavior absorbed social discontent. Both ruling movements were able to deflect the social discontent by drawing public attention to the process for Palestinian statehood (Fatah in the West Bank) or to militant resistance (Hamas in the Gaza Strip) ${ }^{47}$. The Gaza battles in 2012 and 2014 worked to the advantage of Hamas. Its performance against the Israeli military and the perceived violent actions of the Israeli military against civilians diverted popular discontent in the Gaza Strip and West Bank into opposition to the perceived Israeli aggression and any further compromises with Israel ${ }^{48}$. On the other front, the PLO's adherence to the national agenda and withstanding the USA's and Israel's dictates to withdraw its application from the general assembly earned the PLO solidarity. The PLO's praise for statehood and further diplomatic bilateral achievements bolstered the political legitimacy of the PNA/Fatah ${ }^{49}$.

Against this background, Palestinians have made Israel responsible for their impoverishment; Palestine is an occupied nation, after all, despite the imperfections

last modified June 5, 2011, accessed December 16, 2015, https://www.haaretz.com/print-edition/ features/gaza-the-most-facebook-friendly-place-on-earth-1.365970.

46 Naser-ajjab, "Palestinian Youth and the Arab Spring. Learning to Think Critically," 280.

47 For PLO/PNA see Walid Salem, "The Arab Revolutions from a Palestinian Perspective," Palestine-Israel Journal 18, no. 1 (2012), accessed June 21, 2013, http://www.pij.org/details. php?id=1419.

48 Poll: After the Gaza War, Poll (Jerusalem: The Jerusalem media and communication centre (JMCC), October 29, 2014), accessed January 6, 2018, http://www.jmcc.org/documentsandmaps. aspx?id=867.

49 Different polls conducted by the Arab World For Research \& Development (AWRAD) support this conclusion: the Arab World For Research \& Development (AWRAD), "Polls 2011," last modified 2011, accessed May 27, 2015, http://www.awrad.org/category.php?id=LJyJqkNuY1a2012316AXWwuKnHAr7; The Arab World For Research \& Development (AWRAD), "15 December 2012: The Public Mood, UN Vote, Gaza Confrontation, Elections, PA and Government and Evaluation of Leadership," last modified December 15, 2015, accessed May 27, 2015, http://www.awrad.org/page.php?id=riSFCsT2mGa9835242AQsK5JcwUx0; See as well Salem, "The Arab Revolutions from a Palestinian Perspective"; and Hind Khoury, "Palestine-Israel Journal: The Arab Re-Awakening and the Hopes for a Palestinian State," Palestine-Israel Journal 18, no. 1 (2012), accessed May 25, 2015, http://www.pij.org/details.php?id=1416; see as well: Poll: Gaza, Resistance and the UN Bid, Poll (Jerusalem: The Jerusalem media and communication centre (JMCC), December 2012), accessed January 6, 2018, http://www.jmcc.org/documentsandmaps.aspx?id=858. 
of the PNA and Hamas, according to one narrative. While Palestinians are distraught with the mismanagement of the PNA and Hamas, they are also likely to recognize that the government is being prevented from doing much of what it is trying to do because of Israel's right-wing government and the sanctions applied to Palestinian territories. This seems to be one reason why the social movement did not transform its dissatisfaction with the political leadership in either Gaza or the West Bank into a Palestine Spring, such as those which occurred in Tunisia and Egypt. Demands of the youth for radical changes in socio- and politico-economic affairs appear belligerent and distorted after years of Israeli occupation and Palestinian bad governance; the Palestinian youth seems unwilling to tackle radical changes within the current Palestinian system under occupation ${ }^{50}$.

Another factor of the change was the segregation and control of the occupied Palestinian territories (geopolitics and resistance). The OPT are geographically separated by Israeli checkpoints and barriers that have hindered the spread of turmoil throughout the occupied Palestinian territories ${ }^{51}$. Moreover, there are a number of (Israeli and Palestinian) security services that control the OPT and prevent (non-violent) demonstrations against Israeli or Palestinian objectives ${ }^{52}$. Fatah and Hamas were not in favor of radical shifts that would cause a surrender of their power monopoly over their respective areas of influence ${ }^{53}$. In contrast to the first and second Intifadas, the social movement hardly enjoyed the support of political leadership or involvement of major parties/movements. Hamas is no longer part of the opposition in the Gaza Strip. The traditional opposition forces of leftleaning orientation seem ideologically outdated and, comparatively, lack followers and mobilization capabilities. Furthermore, the PNA initiated laws restricting the work of NGOs and advocacy groups. It is likely that Israel was also interested in keeping the status quo of Palestinian politics; it decided to re-start sending money to the PNA during hard times. This explains to a certain degree the questioning or imprisonment of activists by Fatah, Hamas, or Israel ${ }^{54}$.

50 Whereas $72 \%$ of the youth would protest against Israel occupation only $18 \%$ in the Westbank and $21 \%$ in Gaza Strip would demonstrate against the PNA/Hamas, according to The Arab World For Research \& Development (AWRAD), "15 December 2012: The Public Mood, UN Vote, Gaza Confrontation, Elections, PA and Government and Evaluation of Leadership"; Christophersen, Høigilt, and Tiltnes, Palestinian Youth and the Arab Spring, 421-428; different poll conducted by JMCC validates the coherency of these findings: Youth Poll on Politics, Education \& The Future.

51 Fabian Schmidmeier, "A Belated Arab Spring for Palestine?," Qantara, last modified September 27, 2012, accessed May 15, 2015, http://en.qantara.de/print/4506.

52 Ziad AbuZayyad, "The Arab Spring: Progress Report and Conclusions," Palestine-Israel Journal 18, no. 1 (2012), accessed December 24, 2014, http://www.pij.org/details.php?id=1423.

53 Al-Ghoul, "Palestinian Activists Bemoan Their Lost Arab Spring."

54 Karl Vick, "On the Run, the Palestinian Youth Movement May Yet Get Its Way," Time, last modified March 27, 2011, accessed April 15, 2012, http://content.time.com/time/world/arti- 
Thirdly, the Palestinian social movement was fragmented and partially paralyzed along main political factions. Within the abovementioned securitization context, different loyalist forces of Fatah and Hamas made efforts to infiltrate novel youth oppositional movements and promote supporter rallies to counter social movement unrest. In addition, loyalist forces tried to denounce social opposition by making reference to the connections between de-legitimizing the historical leadership and offering free service to the Israel occupation. This stigma discouraged protestors, at certain times, from playing a major part in the social protests ${ }^{55}$. In this sense, classical political parties such as Fatah and Hamas have throttled the youth's contention. Furthermore, classical oppositional parties such as the Popular Front for the Liberation of Palestine (PFLP) or the Democratic Front for the Liberation of Palestine (DFLP) tried to infiltrate social movement and use it to their advantage, which caused demoralization on the part of unaffiliated youth ${ }^{56}$. Unaffiliated political activists who served as organizers for demonstrations diminished over time.

Fourthly, Palestinians have been involved in a struggle against Israeli occupation and expansion policy for decades, and much of the social groups' energies have been exhausted ${ }^{57}$. Waves of demonstrations and historic intifadas were the expression of their will for self-determination. In the meantime, however, the fiasco of the national movement seems evident, and the deadlock of the national project seems apparent for Palestinians in every aspect of their daily life ${ }^{58}$. As an expression of their deep-rooted frustration with such developments, young Palestinians seem to have antipathy towards traditional forms of political engagement due to the lack of a vital role model in Palestine. In the words of Sabri Saidam, former Palestinian Minister of Communications and Technology, "It's the issue of getting bored of the fact that they see leaders who existed for dozens of years. They don't want

cle/0,8599,2061661,00.html; Linah Alsaafin, "Imperfect Revolution: Palestine's 15 March Movement One Year on," Electronic Intifada, last modified March 23, 2012, accessed April 15, 2012, https://electronicintifada.net/content/imperfect-revolution-palestines-15-march-movement-one-year/11092; Yousef Munayyer, "How Intifada Fears Show Only Israeli Security Matters," The Daily Beast, last modified February 27, 2013, accessed March 1, 2018, http://www. thedailybeast .com/articles/2013/02/27/how-intifada-fears-show-only-israeli-security-matters .html; Amos Harel, "Prisoners Are Netanyahu's Double Defence," Haaretz Online, last modified October 28, 2013, accessed January 6, 2018, http://www.haaretz.com/news/diplomacy-defense/. premium-1.554852.

55 "Talks with Previous Gaza-based and Westbank - based Activists in Turkey"; and Al-Ghoul, "Palestinian Activists Bemoan Their Lost Arab Spring."

56 "Talks with Previous Gaza-based and Westbank - based Activists in Turkey"; and Al-Ghoul, "Palestinian Activists Bemoan Their Lost Arab Spring."

57 Marwan Muasher, The Second Arab Awakening And the Battle for Pluralism (New Haven and London: Yale University Press, 2014), 157-158.

58 "Talks with Previous Gaza-based and Westbank - based Activists in Turkey." 
any leaders ${ }^{59}$ ". The loss of structure of the social movement proved ineffective in inducing radical shifts in Palestine. With time, protesters were fewer in number and their voices were not united in demanding the fall of the PNA ${ }^{60}$.

A fifth reason is the rents and cooptation of the PNA/Fatah and Hamas. This factor underlies the political economy of the PNA and Hamas. Both movements have become employers for thousands of Palestinians. The PNA provides the most public sector employment in Palestine. As a receiver of Western foreign aid, the PNA supports national institutions operating under its framework. Hamas on its front, as a receiver of foreign aid, has been distributing aid in the form of rent as welfare measures to its followers and sympathizers. Bearing in mind the great economic hardship in the OPT, Palestinians seem unwilling to take part in a fundamental shift against the ruling movements, for a change in the status quo or the end of the PNA would make them jobless and without welfare aid. In this sense, the revenues of the PNA and Hamas seem to coopt people to the Oslo framework (19932000 ), which has economically proven to be dysfunctional and politically expired ${ }^{61}$. Remarkably, professionals, such as professors or lawyers, who are affiliated to and engaged within the salary framework of the mini-state of Fatah in the West Bank or Hamas in Gaza, seem less inclined to revolt against their benefactors. This contributes to explaining the lack of willingness of the middle class to join the vanguard of the youth movement.

A further reason is that regional and international conditions are not favorable for a radical shift in Palestine. The Arab Spring lost its credentials. Initially, the democratization process across the Middle East was followed by a wave of optimism/ euphoria underlying the prospect of entrenching the Palestinian demand of self-determination vis-à-vis Israel. In the meantime, however, regional polarization and power competition have reverberated across the Middle East. The mood of the time has become rather less optimistic ${ }^{62}$. The agenda of regional politics has changed profoundly. No longer does Palestine seem to be a core principle of Arab regional politics. Palestinians regard themselves as losers of Arab Spring developments ${ }^{63}$. It is likely that such developments and insights were demoralizing for Palestinians

59 Sabri Saidam in an interview with Mozgovaya, "Gaza, the Most Facebook Friendly Place on Earth" the polls cited in this article regarding the popularity of ruling parties support this conclusion.

60 Different polls confirm the lack of will for demonstration among youth: Youth Poll on Politics, Education \& The Future.

${ }^{61}$ For related insights see: Lori Allen, The Rise and Fall of Human Rights: Cynicism and Politics in Occupied Palestine, Stanford studies in human rights (Stanford, California: Stanford University Press, 2013).

62 Amour, "Editor's Note: The End of the Arab Spring?"

63 Amour, "Israel, the Arab Spring, and the Unfolding Regional Order in the Middle East." 
and eroded confidence in changes at home ${ }^{64}$. Palestinians became aware that inter-party reconciliation and rapprochement is not solely a domestic issue; instead, the regional environment is not favorable for intra- and inter-party reconciliation and rapprochement ${ }^{65}$.

\section{Conclusions}

New challenges have unfolded in the wake of the Arab Spring movement for Fatah and Hamas. In addition to their mutual antagonism and the ongoing quest for the leadership of the Palestinians, the regional shifts in the Middle East have involved the need to address public demonstrations and potential social disobedience in the $\mathrm{OPT}^{66}$. Notably, the leaderships in the West Bank (PNA/Fatah) and in the Gaza Strip (Hamas) demonstrate comparable interior challenges, which are similar to those of other Middle Eastern or Arab states: lack of freedom, corruption, and lack of prospects for the youth. So far, Palestinian movements have been unable to make the political and socio-economic shifts that they have promised their public audiences, which calls into question the viability of the national strategies and the legitimacy of the current political leaderships. Additionally, the national division has proven to be irreconcilable in spite of repeated appeals for unification from the Palestinians. These factors have caused, among others, the decrease in the political legitimacy of Fatah and Hamas. Thus, crucial alterations in Palestinian politics seemed underway in light of the revolutionary stimuli of the Arab Spring movement.

The Arab Spring generated an authentic and undeniable zeitgeist of change and anticipation in the Arab World. In Palestine, it produced high spirits and high hopes for a better future. With such authentic drive, Palestinians felt that they had a substantial momentum driving them to fulfill their national aspirations, which appeared to be realistically on the horizon. ${ }^{67}$ Palestinians assumed that if revolutionary groups in other parts of the Arab World were able to replace their repressive regimes with genuinely elected governments, then they too would be able to move in a similar direction, which would inexorably lead them to selfdetermination (i.e., national unity and independent sovereign statehood) ${ }^{68}$. The social movement demanded an end to the national rift between Fatah and Hamas, political reforms of the PLO, and adjustment of the Paris Protocol.

64 Ageel, "A Palestinian Uprising," 284-285.

65 Amour, "Hamas-PLO/Fatah Reconciliation and Rapprochement within the Unfolding Regional Order in the Middle East since 2010:"

66 Ghanem, "The Palestinians - Lessons from the Arab Spring," 435-436; Elgindy, "The Palestinians," 128-136.

67 For the aspect of hope Shlaim, "Israel, Palestine, and the Arab Uprisings," 381, 388.

68 The Palestinian youth recognized the Arab Spring movement as a model and stimulus for their social movement. See Erakat, "Palestinian Youth." 
At first, both rival movements attempted to suppress the waves of protest to maintain their hold on power. As the intensity of protests increased, both movements showed a willingness to meet and put an end to the national divide. Both ruling movements also initiated tactical bargains in an appeasing and absorbing strategy towards the demands of the protesters. For instance, both entities in the Gaza Strip and the West Bank attempted to promote their capacity to improve human conditions, increase the rule of law and improve administrative capability in order to absorb public contention. With regard to inter-movement reconciliation, Fatah and Hamas held multiple meetings of reconciliation. However, like other actors in the Middle East, Fatah and Hamas could not escape the yoke of power competition, regional polarization, and regional alignments, all of which collided with domestic rapprochement and unification ${ }^{69}$.

Survival and self-interest enjoyed the upper hand within both Fatah and Hamas as they aimed to address the demands for national reconciliation and to shore up political legitimacy. For Fatah and Hamas, the consolidation of domestic and regional pre-Arab Spring status or its maximization in the context of unfolding regional developments seemed more relevant than ever ${ }^{70}$. Thus, in addition to delivering lip service to national rapprochement, both parties maneuvered against each other, each committed to conceding to the other as little as possible. The regional dynamics effected the choices of both movements and produced negative consequences for each side (i.e., Fatah, then Hamas), resulting in a positive strategic impact for the other side (i.e., Hamas, then Fatah). This relation changed moderately as regional dynamics unfolded and prevented reconciliation, reinforcing the division ${ }^{71}$. Moreover, tactical tensions within the leadership of Hamas and of the PLO/Fatah have complicated and hindered the implementation of conciliatory treaties ${ }^{72}$. These fluctuating and destabilizing domestic and regional factors have hindered the development of national unity, so that the division and dissension between Fatah and Hamas continues. Economic hardships persist. Such elements are further indications of the fiasco of the Palestinian national project.

69 Amour, "Hamas-PLO/Fatah Reconciliation and Rapprochement within the Unfolding Regional Order in the Middle East since 2010."

70 Khalil Shikaki, "Coping with the Arab Spring: Palestinian Domestic and Regional Ramifications," Middle East Brief, no. 58 (December 2011): 5; Basem Ezbidi, ““Arab Spring': Weather Forecast for Palestine," Middle East Policy 20, no. 3 (Fall 2013): 102-108.

71 Amour, "Hamas-PLO/Fatah Reconciliation and Rapprochement within the Unfolding Regional Order in the Middle East since 2010:"

72 Alquds Al-Arabi Online, "Opposition within Hamas and the PLO on the Doha Declaration and Fayyad May Remain as Finance Minister [in Arabic]," last modified February 7, 2012, accessed December 15, 2013, www.alquds.co.uk. 
The social movements since 2011 have not produced radical shifts in the OPT due to the interrelated factors introduced above. The Palestinian social movement appeared weak and fragmented; protestors were divided in their affiliations and organizational preferences. The abovementioned factors have cut short the social movement, causing deficiencies in the social dynamics and youth activists' networks in terms of durable demonstrations and enthusiasm against the PNA/Fatah and Hamas. The social movement could not gain the support of the middle class or professionals for an enduring and consistent movement against the political elite. In retrospect, two factors appear important for understanding this development: (1) younger Palestinians refrain from organizational and hierarchical political activism due to their disqualification of Fatah and Hamas as role models and the lack of role models in the Palestinian arena and (2) the occupational policies of Israel's right-wing government against the Palestinians, regional risks, and international pressure on the Palestinian leaderships absorbed public discontent; Palestinians did not attempt to tackle their leadership. Such findings are not conclusive and require further analysis. While the contemporary Palestine Spring was linked to reforms, future revolts may develop radically against the political leadership.

Despite the failure of the social movement to generate a radical change in the OPT (similar to the Tunisian and Egyptian examples), national contention and protests caused significant repercussions for Palestinian politics, some symbolic and others of a more substantive nature. The dynamics of the Palestine Spring challenged both the moderate model of state-building (of Fatah) and the historicalmilitant model of the restoration of Palestine (currently dominated by Hamas) ${ }^{73}$. It provided opportunities for both streams to reassess their strategic-tactical doctrines.

The leadership of the PLO/Fatah reevaluated its approach to bilateral peace negotiations with Israel's right-wing government after years of the blockade in peace talks. It made efforts to enhance its standing internationally and to foster the development of an independent and sovereign Palestinian state. Signing bilateral agreements with individual states and integrating with international governmental organizations as legitimizing powers to enhance Palestine's legal standing are examples of such novel policy orientations ${ }^{74}$. Remarkably, during the Palestine Spring, it became palpable that the (old) revolutionary guards of Fatah and Hamas were no longer untouchable and that the PLO's peace approach must go hand in hand with Israel's willingness for mutual peace. Such dynamics encouraged Fatah to rebrand itself in the occupied Palestinian territories not only as a peace maker but also as a resistance

73 See Amour, "Palestinian Politics in Transition: The Case of the October War."

74 Amour, "Hamas-PLO/Fatah Reconciliation and Rapprochement within the Unfolding Regional Order in the Middle East since 2010:" 
faction ${ }^{75}$. One side-effect of regional dynamics and the Palestine Spring was causing intra-movement rifts within Hamas to surface. The exile leadership around Khaled Mashal was more in favor of compromises towards Fatah, whereas the local leadership was less inclined towards the implementation of the reconciliation deals.

There was widespread optimism among Palestinians when the PLO gained the recognition of the United Nations and when Hamas achieved real, perceived, or imaginary paramilitary and diplomatic triumphs over Israel. However, since those times, diplomatic achievements have not blossomed rapidly; paramilitary achievements remain limited. Crucial alterations in Palestinian politics are underway, and politics in Palestine remain at a crossroads. From a Palestinian point of view, the second decade of the $21^{\text {st }}$ century is a lost decade due to the lack of major developments in their national cause and the persistence of national division.

Peer-review: Externally peer-reviewed.

Conflict of Interest: The author has no conflict of interest to declare.

Financial Disclosure: The author declared that this study has received no financial support.

Hakem Değerlendirmesi: Dış bağımsız.

Çıkar Çatışması: Yazar çıkar çatışması bildirmemiştir.

Finansal Destek: Yazar bu çalışma için finansal destek almadığını beyan etmiştir.

\section{Bibliography}

Abou-El-Fadl, Reem. "The Road to Jerusalem through Tahrir Square: Anti-Zionism and Palestine in the 2011 Egyptian Revolution." Journal of Palestine Studies 41, no. 2 (January 2012): 6-26.

Abu Toameh. "Palestinian Affairs: Will the Palestinians Rise up Too?" The Jerusalem Post. Last modified March 11, 2011. Accessed August 8, 2014. http:// www.jpost.com/LandedPages/PrintArticle.aspx?id=211680.

Abu-Shahla, Rawan. "Why Palestinians Will Protest on 15 March." The Electronic Intifada. Last modified March 14, 2011. Accessed December 16, 2017. https:/electronicintifada.net/content/why-palestinians-will-protest-15-march/9823.

75 Regarding Hamas, see also Ahmed Masoud, "The Arab Spring: A Palestinian Perspective," last modified December 9, 2011, accessed September 1, 2015, https://ceasefiremagazine.co.uk/arab-spring-palestinian-perspective/; Khalil Shikaki, "Can Hamas Moderate? Insights from Palestinian Politics during 2005-2011,” Middle East Brief, no. 88 (January 2015): 1-10. 
AbuZayyad, Ziad. "The Arab Spring: Progress Report and Conclusions." Palestine-Israel Journal 18, no. 1 (2012). Accessed December 24, 2014. http:// www.pij.org/details.php?id=1423.

Ageel, Ghada. "A Palestinian Uprising: Is It Possible or Is It Too Late?" Sociology of Islam 2, no. 3-4 (June 10, 2014): 283-309.

Al-Ghoul, Asmaa. "Palestinian Activists Bemoan Their Lost Arab Spring." Al-Monitor. Last modified January 18, 2013. Accessed January 4, 2018. https:// www.al-monitor.com/pulse/originals/2013/01/palestine-failed-arab-spring.html.

Aliboni, Roberto. "The International Dimension of the Arab Spring." The International Spectator 46, no. 4 (December 2011): 5-9.

Allen, Lori. The Rise and Fall of Human Rights: Cynicism and Politics in Occupied Palestine. Stanford studies in human rights. Stanford, California: Stanford University Press, 2013.

Alquds Al-Arabi Online. "Opposition within Hamas and the PLO on the Doha Declaration and Fayyad May Remain as Finance Minister [in Arabic]." Last modified February 7, 2012. Accessed December 15, 2013. www.alquds.co.uk.

Alsaafin, Linah. "Imperfect Revolution: Palestine's 15 March Movement One Year on." Electronic Intifada. Last modified March 23, 2012. Accessed April 15, 2012. https://electronicintifada.net/content/imperfect-revolution-palestines-15-march-movement-one-year/11092.

Amour, Philipp O. "Editor's Note: The End of the Arab Spring?" Edited by Philipp O. Amour. The Arab Spring: Comparative Perspectives and Regional Implications, Special issue, Alternatives: Turkish Journal of International Relations, 12, no. 3 (Fall 2013): I-IV.

Amour, Philipp O. "Hamas-PLO/Fatah Reconciliation and Rapprochement within the Unfolding Regional Order in the Middle East since 2010: Neorealist and Neoclassical Realist Perspectives." Journal of Social Sciences of Mus Alparslan University 6, no. 5 (April 13, 2018): 621-31. https://doi.org/10.18506/ anemon.384773.

Amour, Philipp O. "Israel, the Arab Spring, and the Unfolding Regional Order in the Middle East: A Strategic Assessment." British Journal of Middle Eastern Studies, May 24, 2016, 1-17. https://doi.org/10.1080/13530194.2016.1185696.

Amour, Philipp O. "Palestinian Politics in Transition: The Case of the October War.” In The Yom Kippur War: Politics, Legacy, Diplomacy, edited by Asaf Siniver, 137-54. Oxford ; New York: Oxford University Press, 2013. 
Amour, Philipp O. "Revolutionary Changes, Power Dynamics, and Regional Rivalries since the Arab Spring: An Introduction.” In The Middle East Reloaded: Revolutionary Changes, Power Dynamics, and Regional Rivalries since the Arab Spring, edited by Philipp O. Amour, 1-21. St. James's Studies in World Affairs. Washington: Academica Press, 2018.

Amour, Philipp O. "The Arab Spring Movement: The Failed Revolution. Preliminary Theoretical and Empirical Deliberation." In The Middle East Reloaded: Revolutionary Changes, Power Dynamics, and Regional Rivalries since the Arab Spring, edited by Philipp O. Amour, 199-224. St. James's Studies in World Affairs. Washington: Academica Press, 2018.

Amour, Philipp O., ed. The Middle East Reloaded: Revolutionary Changes, Power Dynamics, and Regional Rivalries since the Arab Spring. St. James's Studies in World Affairs. Washington, DC: Academica Press, 2018.

Ashrawi, Hannan. "Palestine and the Arab Spring", Summary of Discussion Hosted by Carnegie Endowment for International Peace." Washington DC, 2011. http://carnegieendowment. org/2011/05/27/palestine-and-arab-spring/1qb (accessed 09 Mai 2013).

Bresheeth, Haim. "The Arab Spring: A View from Israel." Middle East Journal of Culture and Communication 5, no. 1 (January 1, 2012): 42-57.

Brownlee, Jason. Democracy Prevention: The Politics of the U.S.-Egyptian Alliance. Cambridge [England] New York: Cambridge University Press, 2012.

Burton, Guy. "Building Ties across the Green Line: The Palestinian 15 March Youth Movement in Israel and Occupied Palestinian Territory in 2011." Third World Quarterly 38, no. 1 (January 2, 2017): 169-184.

Christophersen, Mona, Jacob Høigilt, and Åge A. Tiltnes. Palestinian Youth and the Arab Spring. Norway: Norwegian peacebuilding resource centre (NOREF), February 2012. http://www.peacebuilding.no/var/ezflow_site/storage/original/application/562d62ccb49d92227b6865a8b2d11e1a.pdf.

Dabashi, Hamid. The Arab Spring: The End of Postcolonialism. London; New York : New York: Zed Books ; Distributed in the USA exclusively by Palgrave Macmillan, 2012.

Elgindy, Khaled. "The Palestinians: Between National Liberation and Political Legitimacy." In The Arab Awakening: America and the Transformation of the Middle East, 128-137. Saban Center at the Brookings Institution book. Washington, DC: Brookings Institution Press, 2011. 
Erakat, Noura. "Palestinian Youth: New Movement, New Borders." Aljazeera. Last modified May 4, 2011. Accessed April 3, 2016. http://www.aljazeera. com/indepth/features/2011/05/201153101231834961.html.

Ezbidi, Basem. “"Arab Spring': Weather Forecast for Palestine.” Middle East Policy 20, no. 3 (Fall 2013): 99-110.

Ezzat, Ashraf. “"Third Intifada Underway', Dissident Voice, 9 May 2011.” Third Intifada Underway. Last modified May 9, 2011. Accessed March 3, 2012. http://dissidentvoice. org/2011/05/third-intifada-underway.

Ghanem, As'ad. "The Palestinians - Lessons from the Arab Spring." Contemporary Arab Affairs 6, no. 3 (July 2013): 422-437.

Harel, Amos. "Prisoners Are Netanyahu's Double Defence." Haaretz Online. Last modified October 28, 2013. Accessed January 6, 2018. http://www.haaretz. com/news/diplomacy-defense/.premium-1.554852.

Khoury, Hind. "Palestine-Israel Journal: The Arab Re-Awakening and the Hopes for a Palestinian State." Palestine-Israel Journal 18, no. 1 (2012). Accessed May 25, 2015. http://www.pij.org/details.php?id=1416.

Lodgaard, Sverre. External Powers and the Arab Spring. Oslo: Scandinavian Academic Press, 2016.

Lynch, Marc. The New Arab Wars: Uprisings and Anarchy in the Middle East. United States of America: Public Affairs, 2017.

Masoud, Ahmed. "The Arab Spring: A Palestinian Perspective." Last modified December 9, 2011. Accessed September 1, 2015. https://ceasefiremagazine. co.uk/arab-spring-palestinian-perspective/.

Mozgovaya, Natasha. "Gaza, the Most Facebook Friendly Place on Earth." Haaretz Online. Last modified June 5, 2011. Accessed December 16, 2015. https:// www.haaretz.com/print-edition/features/gaza-the-most-facebook-friendly-placeon-earth-1.365970.

Muasher, Marwan. The Second Arab Awakening And the Battle for Pluralism. New Haven and London: Yale University Press, 2014.

Munayyer, Yousef. "How Intifada Fears Show Only Israeli Security Matters." The Daily Beast. Last modified February 27, 2013. Accessed March 1, 2018. http://www.thedailybeast .com/articles/2013/02/27/how-intifada-fears-show-only-israeli-security-matters .html.

Naser-Najjab, Nadia. "Palestinian Youth and the Arab Spring. Learning to Think Critically: A Case Study." Contemporary Arab Affairs 5, no. 2 (April 2012): 279-291. 
Odgaard, Lena. "Protesters Signal Political Crisis For the Palestinian Authority." Al-Monitor: The Pulse of the Middle East. Last modified September 10, 2012. Accessed May 10, 2015. http://www.al-monitor.com/pulse/originals/2012/al-monitor/do-not-publish--west-bank-protes.html\#.

Pace, Michelle, and Francesco Cavatorta. "The Arab Uprisings in Theoretical Perspective - An Introduction." Mediterranean Politics 17, no. 2 (July 2012): 125-138.

Pratt, Nicola. "The 'Arab Spring' and the Israel-Palestine Conflict: Settler Colonialism and Resistance in the Midst of Geopolitical Upheavals." Ortadoğu Etütleri (Journal of Politics and International Relations) 5, no. 1 (July 2013): 9-40.

Ravid, Barak. "Fayyad's Resignation: The Beginning of the End of the PA?" Haaretz Online, April 14, 2013. Accessed May 2, 2013. http://www.haaretz. $\mathrm{com} /$ news/middle-east/fayyad-s-resignation-the-beginning-of-the-end-of-thepa-1.515292.

Rudoren, Jodi, and Akram Fares. "Palestinians Sign Deal to Set Up Elections." NYTimes.Com. Last modified May 20, 2012. Accessed May 20, 2015. http:// www.nytimes.com/2012/05/21/world/middleeast/hamas-and-fatah-agree-in-cairoto-begin-work-on-elections.html?_r=0.

Salem, Walid. "The Arab Revolutions from a Palestinian Perspective." Palestine-Israel Journal 18, no. 1 (2012). Accessed June 21, 2013. http://www.pij.org/ details.php?id=1419.

Schmidmeier, Fabian. "A Belated Arab Spring for Palestine?" Qantara. Last modified September 27, 2012. Accessed May 15, 2015. http://en.qantara.de/ print $/ 4506$.

Shikaki, Khalil. "Can Hamas Moderate? Insights from Palestinian Politics during 2005-2011.” Middle East Brief, no. 88 (January 2015): 1-10.

. "Coping with the Arab Spring: Palestinian Domestic and Regional Ramifications." Middle East Brief, no. 58 (December 2011): 1-8.

Shlaim, Avi. "Israel, Palestine, and the Arab Uprisings." In The New Middle East: Protest and Revolution in the Arab World, edited by Fawaz A. Gerges, 380-401. New York: Cambridge University Press, 2014.

Snyder, Richard Carlton, H. W. Bruck, Burton M. Sapin, and Valerie M. Hudson, eds. Foreign Policy Decision-Making Revisited. New York: Palgrave Macmillan, 2002.

Stoffel, Derek. "Palestinian Youth Uprising Faces Uncertainty as Clashes with Israel Increase.” CBC News. Last modified November 17, 2014. Accessed Jan- 
uary 9, 2018. http://www.cbc.ca/news/world/palestinian-youth-uprising-faces-uncertainty-as-clashes-with-israel-increase-1.2837116.

The Arab World For Research \& Development (AWRAD). "15 December 2012: The Public Mood, UN Vote, Gaza Confrontation, Elections, PA and Government and Evaluation of Leadership." Last modified December 15, 2015. Accessed May 27, 2015. http://www.awrad.org/page.php?id=riSFCsT2mGa9835242AQsK5JcwUx0.

The Arab World For Research \& Development (AWRAD). "Polls 2011." Last modified 2011. Accessed May 27, 2015. http://www.awrad.org/category.php?id=LJyJqkNuY1a2012316AXWwuKnHAr7.

Tuastad, Dag. "Hamas-PLO Relations Before and After the Arab Spring." Middle East Policy 20, no. 3 (September 2013): 86-98.

ValbjøRn, Morten, and André Bank. "The New Arab Cold War: Rediscovering the Arab Dimension of Middle East Regional Politics." Review of International Studies 38, no. 01 (January 2012): 3-24.

Vick, Karl. "On the Run, the Palestinian Youth Movement May Yet Get Its Way." Time. Last modified March 27, 2011. Accessed April 15, 2012. http://content. time.com/time/world/article/0,8599,2061661,00.html.

"Abbas to Head Palestinian Unity Government." Al Jazeera English. Last modified February 7, 2012. Accessed May 20, 2015. http://www.aljazeera.com/ news/middleeast/2012/02/20122610416298264.html.

“Agreement between Fatah and Hamas," May 3, 2011. Accessed May 20, 2015. http://peacemaker.un.org/sites/peacemaker.un.org/files/OPt_AgreementFatahHamas2011.pdf.

“Herak Shababi Mustakel.” Facebook. Accessed December 20, 2017. https:// www.facebook.com/pg/Herak.Shababi/about/?ref=page_internal.

"How Did the Palestinian National Unity Government Perform during Its First Year [in Arabic]?" Arab Reality. Aljazeera Net, June 2, 2015. http://www.aljazeera.net/programs/arab-present-situation/2015/6/2.

"Palestine: Palestinian Authority Police Beat Protesters." HRW. Last modified July 30, 2013. Accessed January 10, 2018. https://www.hrw.org/news/2013/07/30/ palestine-palestinian-authority-police-beat-protesters.

"Palestine Papers: Al Jazeera, Guardian Release Documents On Israeli-Palestinian Conflict." Accessed May 20, 2015. http://www.huffingtonpost. com/2011/01/23/palestine-papers-israel-conflict-wikileaks-documents-released_n_812776.html\#13_harsh-words-for-all-sides. 
"Palestinians for Dignity." Facebook. Accessed December 20, 2017. https:// www.facebook.com/palestiniansfordignity.

Poll: After the Gaza War. Poll. Jerusalem: The Jerusalem media and communication centre (JMCC), October 29, 2014. Accessed January 6, 2018. http://www. jmcc.org/documentsandmaps.aspx?id=867.

Poll: Gaza, Resistance and the UN Bid. Poll. Jerusalem: The Jerusalem media and communication centre (JMCC), December 2012. Accessed January 6, 2018. http://www.jmcc.org/documentsandmaps.aspx?id=858.

"Salam Fayyad." The New York Times. Accessed May 15, 2014. http://topics.nytimes.com/top/reference/timestopics/people/f/salam_fayyad/index.html.

"Talks with Previous Gaza-based and Westbank - based Activists in Turkey," 2016, 20172015.

“The Palestine Papers." Al Jazeera English. Last modified January 2011. Accessed May 20, 2015. http://www.aljazeera.com/palestinepapers/.

"The Palestine Papers: The Documents." The Guardian. Last modified February 1, 2011. Accessed May 20, 2015. http://www.theguardian.com/world/series/ palestine-papers-documents.

"Why Are People Protesting in Iran?" Aljazeera Online. Last modified December 30, 2017. Accessed December 31, 2017. http://www.aljazeera.com/amp/ news/2017/12/people-protesting-iran-171230083612254.html?_twitter_impression=true.

"Will We Always Have Paris?" Gaza Gateway | Facts and Analysis about the Crossings. Last modified September 13, 2012. Accessed May 10, 2015. http://gisha. org/en-blog/2012/09/13/will-we-always-have-paris/.

Youth Poll on Politics, Education \& The Future. Poll. Jerusalem: The Jerusalem media and communication centre (JMCC), October 9, 2016. Accessed December 6, 2018. http://www.jmcc.org/documentsandmaps.aspx?id=873.

Youth Poll on Politics, Social Media and Conservatism. Poll. Jerusalem: The Jerusalem media and communication centre (JMCC), April 2016. Accessed January 6, 2018. http://www.jmcc.org/documentsandmaps.aspx?id=871. 